\title{
MANAGEMENT SUPPORT PRACTICES TO PROMOTE TEACHERS' INSTRUCTIONAL IMPROVEMENT FOR SUSTAINABLE DEVELOPMENT IN SECONDARY EDUCATION
}

\author{
Akinfolarin Akinwale Victor \\ Department of Educational Management and Policy, Nnamdi Azikiwe University, Awka, \\ Anambra State, Nigeria. \\ Professor Uche Grace Emetarom \\ Department of Educational Administration and Planning, Abia State University, Uturu, Abia \\ State, Nigeria.
}

Article DOI: https://doi.org/10.36713/epra1718

\begin{abstract}
This study ascertained the principals' management support practices to promote teachers' instructional improvement forsustainable development in secondary education in Anambra State. Two specific purposes were formulated and two research questions guided the study. The study adopted a descriptive survey design. The study was conducted in the six education zones in Anambra Statenamely:Aguata, Awka, Nnewi,Ogidi,Onitsha and Otuocha.The study population comprised 257 principals in public secondary schools in the six education of the State. No sampling was used due to the manageable size of the population. The instrument used for data collection is a structured 15 items researchers' developed instrument titled; Principals' Management Support Practices to Promote Teachers' Instructional Improvement Questionnaire (PMSPTIIQ). The face validation of the instrument was established by three research experts. The Cronbach alpha was used to determine the reliability of the instrument. Coefficient value of 0.84 was obtained. Data were analyzed using mean and standard deviation. The findings of the study revealed among others that secondary school principals in Anambra State do not engage in instructional supervision practices of observing classroom instruction to ensure cur iculum coverage, monitoring teachers' compliance to school schedules, meeting regularly with teachers to discuss instructional challenges and providing feedback to teachers after class observation. The study also found out that secondary school principals' do not engage in adequate motivational practices to promote teachers' instructional improvement for sustainable development in secondary education in Anambra State. Based on the findings, it was recommended that school administrators' should always engage in instructional supervision practices by observing classroom instruction to ensure cur iculum coverage, monitoring teachers' compliance to school schedules, meeting regularly with teachers to discuss instructional challenges and providing feedback to teachers after class observation among others. Conclusion wasdrawn.
\end{abstract}

KEYWORDS: principals', management support practices, instructional improvement, sustainable development 


\section{INTRODUCTION}

Principals' by virtue of their position are the managers and the quality of managerial functions determine to a large extent their success or failure (Odumodu, 2011). Principals should as wellprovide teachers with needed management support to effectively function in their schools (Castller, 2010). Peretomode (2013), opined that management practices are the social interaction processes involving a sequence of co-ordinated events of planning, organizing, coordinating, appraising monitoring and controlling employed to use available resources to achieve a desired outcome in the fastest and most efficient way. Management support practices are integral part of management practices provided to enhance workers productivity. Nwite (2016) pointed out that management support practices include: the provision of supervision, motivation, professional growth and welfare. For the purpose of this study, management support practices in schools involve the provision of supervision, motivation, ensuring professional development of staff and application of other supportive management functions to improve instructional delivery for the attainment of school goals and objectives. Management support practices are geared towards providing a friendly climate for workers productivity. Supervising and motivating workers is central to management support practices.

According to Osakwe (2010), supervision is concerned with the provision of professional assistance and guidance to teachers geared towards the achievement of effective teaching and learning in the school. The duty of manager as a leader in the organization is to identify the strengths and weaknesses of their supervisees and other subordinates in order to guide and assist them professionally to achieve their targets and those of the organization as well. Burton, Carper and William (2011) summarized supervision as "efforts made by the school head to support teachers to become more effective in their job and equally access professional development on the job". Clark (2015) on the other hand sees supervision as a task of improving instruction through regular monitoring and in-service education of teachers. Supervision is seen as a process of bringing about improvement in instruction by working with people who are working with pupils and students (Emetarom, 2007).

Instructional supervision, according to Okobia (2015) is a helping relationship whereby the supervisor guides and assists the teachers to meet the set targets. Instructional Supervision in this context can be defined as the technical monitoring and professionally guiding teachers and learners to achieve their goals thereby promoting instructional delivery within the school. Instructional supervision, being part of management support practices will not only provide professional assistance to teachers but will equally help to identify strengths and weaknesses in teaching and learning process forpossible solutions. School managers and supervisors should be competent in identifying teachers' needs and their sources of motivation to ignite their interest in quality teaching and learning.

Michaelowa in Akinfolarin and Ehinola (2014) sees motivation as the "willingness, drive or desire to engage in good teaching". It is the desired force that compel individual to willingly perform certain tasks or behave in a particular manner. Teachers' motivation is one of the important factors in realizing educational objectives by achieving high academic performance. Teachers are charged with otherresponsibilities such as guiding,counseling,discipliningstudents, managing classes and participating in cur iculum development panels other than teaching (Yuniah, Walter \& Duke, 2015). Teachers should be rewarded for their unquantifiable efforts through prompt payment of salaries, promotion, involvement in decision making, professional development, due recognition, good welfare policies among others. Akinfolarin and Ehinola (2014) revealed in a study that provision of regular payment of salary and other remuneration by the head promotes the performance of academic staff. Principals should engage in motivational practices like prompt payment of salary and other remuneration, performance appraisal, provision of physicalfacilities,involvement in decision making, good relationship, promotion, welfare packages, and on the job development programs for growth to promote teachers productivity. Provision of managementsupport practices by school principals are essential for teachers'performancein building sufficiently motivated and effective teachers (Nwite, 2016). In other to have a sustainable teaching and learning process, it is important for principals as school managers to adopt suitable management support practices for instructional improvement.

Instructional improvement is about managerial inputs leading to progressive change in teachers' instructional delivery. Akinfolarin and Rufai(2017)posit thatinstructional improvement is the act of making progress in instructional delivery for better academic achievement. The successful teaching and learning processes leading to outstanding academic achievement of students' is an indication of instructional improvement. Instructional improvement involves the application of management practices and creating enabling school climate thereby, advancing teaching and learning process leading to student academic performance. 


\section{EPRA International Journal of Research and Development (IJRD) \\ Volume: 5 | Issue: 2 | February 2020 \\ - Peer Reviewed Journal}

Instructional improvement and school goals can be realized through effective management support practices in the areas of instructional supervision, motivation and appropriate use of school resources. The rationale behind management support practices is to encourage and stimulate workers for better performance. Teachers should be given adequate support and enabling environment to increase their commitment to instructional tasks.

The concept of sustainabledevelopment has assumed much relevance not only to environmental and biodiversity issues but also to education practice (Akpan \& Onabe, 2016).

Nwanekwe (2009) defined sustainable development as maintenance of a steady growth and improvement in the people's ability and capacity, discipline responsibility and material well-being. It is the overall uninterrupted growth and well-being of the people in various aspects. Change and sustainable development occur in the education sector just like every other sector. There are emerging trend in all aspect of the economy which requires leaders and managers to adapt to this changing environment for sustainable development. Sustaining teachers' instructional improvement in a functional secondary education is imperative towards the realization of educational goals. Effective supervision, motivational strategies, good relationship, professional development, involving staff in decision making, democratic environment and good welfare and incentives policies are components of management support practices. However, the attention of this study is on supervision and motivation.

\section{STATEMENT OF THE PROBLEM}

School administratorsare expected to provide enablingenvironment through management support practices forimproved teaching and learning. Negative indicators coming from secondary level of education over poor teachers performance on instructional delivery leading to low academic achievement of students is of great concern to stakeholders. It appears that principals do not effectively provide and adopt the appropriate management support practices for teachers in areas of instructional supervision and motivating teachers to improve their instructional delivery in schools. It is against this problem that this study aimed to determine principals' management support practices to promote teachers' instructional improvement for sustainable development secondaryeducationinAnambraState.

\section{PURPOSE OF THE STUDY}

The purpose of this study is to determine Principals' Management Support Practices to Promote Teachers'
Instructional Improvement for Sustainable Development in Secondary Education in Anambra State, Nigeria. Specifically, this study set out to determine:

1. Principals' Instructional Supervision Practices to Promote Teachers' Instructional Improvement for Sustainable Development in Secondary Education in Anambra State, Nigeria.

2. Principals' Motivational Practices to Promote Teachers' Instructional Improvement

forSustainableDevelopmentinSecondary EducationinAnambraState,Nigeria.

\section{RESEARCH QUESTIONS}

3. What are Principals' Instructional Supervision Practices to Promote Teachers' Instructional Improvement for Sustainable Development in Secondary Education in Anambra State,Nigeria?

4. What are Principals' Motivational Practices to Promote Teachers' Instructional Improvement for Sustainable Development in Secondary Education in Anambra State,Nigeria?

\section{METHOD}

The study adopted a descriptive survey design and was conducted in Anambra State. The study population comprised 257 principals in public secondary schools in the State. No sampling was used due to the manageable size of the population. The instrument used fordata collection was a structured 15 items researchers' developed instrument titled; Principals' Management Support Practices to Promote Teachers' Instructional Improvement Questionnaire (PMSPTIIQ). The response format of the questionnaire was structured on a fourpoint rating scale of Strongly Agree (SA),Agree(A),Disagree(D)andStronglyDisagree(SD) weighted $4,3,2$ and 1 respectively. The face validation of the instrument was established by three experts, two in the Department of Educational Management and Policy and one in the Department of Educational

(MeasurementandEvaluationUnit),Faculty

ofEducation,Nnamdi Azikiwe University University. The Cronbach alpha was used to determine the reliability of the instrument. Coefficient value of 0.84 was obtained. Data were analyzed using mean and standard deviation. The questionnaire were administered by the researchers together with five research assistants who were briefed on how to approach the principals. The mean responses were adjudged on the following basis of any mean score of 
2.50 orabove is taken to indicate agreement while any mean score that fallsbelow 2.50 is taken as disagreement.

\section{RESULTS}

Research Question 1: What are Principals' Instructional Supervision Practices to Promote
Teachers' Instructional Improvement for Sustainable Development in Secondary Education in Anambra State, Nigeria?

Table 1: Mean scores and standard deviation ratings of principals' instructional supervision practices to promote teachers' instructional improvement in secondary education.

$\begin{array}{llll}\text { S/N } & X & S D & \text { Decision }\end{array}$

1. Observing classroom instruction to ensure cur iculum coverage

2.Checkingofteachers'lessonplanandlessonnotesforpossible

3. Checking teachers record of work done to monitortheirprogress

4. Monitorteachers' compliance to school schedules

5. Monitoring teachers' use of instructional materials

6. Meeting regularly with teachers to discuss instructional challenges

7. Provision of feedback to teachers afterclass observation

\section{$1.34 \quad 0.77 \quad$ Disagree}

$3.68 \quad 0.34 \quad$ Agree

$2.590 .93 \quad$ Agree

$2.120 .46 \quad$ Disagree

$2.750 .90 \quad$ Agree

$\begin{array}{lll}2.39 & 0.22 \quad \text { Disagree }\end{array}$

$2.22 \quad 0.49 \quad$ Disagree

\section{GrandMeanandStandardDeviation}

Items 2, 3 and 5 on table 1 are above the mean score of 2.50 which indicate that respondents' agreed with the statements while items $1,4,6$ and 7 mean scores are below 2.50 which indicate that respondents' disagreed with the statements. The grand mean score of 2.44 which is below the accepted mean score of 2.50 indicates disagreement in principals' instructional supervision practicesto promote teachers' instructional improvement for sustainable development in

\section{$2.44 \quad 0.59 \quad$ Disagree}

Research Question 2: What are Principals' Motivational Practices to Promote Teachers' Instructional Improvement for Sustainable Development in Secondary Education in Anambra State, Nigeria? 


\section{EPRA International Journal of Research and Development (IJRD) \\ Volume: 5 | Issue: 2 | February 2020 \\ - Peer Reviewed Journal}

Table 2: Mean scores and standard deviation ratings of principals' motivational practices to promote teachers' instructional improvement in secondary education.

\begin{tabular}{lcccc}
\multicolumn{1}{c}{ Items } & \multicolumn{1}{c}{ S } & SD & Decision \\
\cline { 2 - 3 } 8. Recommending teachers forpromotion as at when due & 2.54 & 0.68 & Agree \\
9. Acknowledging teachers' instructional achievement openly & 2.25 & 0.33 & Disagree \\
10. Involving teachers in decision making on instructionalprogress & 2.67 & 0.50 & Agree \\
11. Providing instructional facilities to enhance instructional delivery & 2.48 & 0.77 & Disagree \\
12. Establishing goodrelationship with teachers & 2.93 & 0.51 & Agree \\
13. Facilitating prompt payment of salary and allowances & 1.41 & 0.88 & Disagree \\
14. Providing adequate chances forprofessional growth and & 2.95 & 0.16 & Agree
\end{tabular}
research development
15. Awarding teachers with impressive titles to boost theirmorale
1.22
0.75
Disagree
Grand Mean and Standard Deviation
$2.310 .57 \quad$ Disagree

Items $8,10,12$ and 14 on table 2 are above the mean score of 2.50 which indicate that respondents' agreed with the statements while item 9, 11, 13, and 15 mean scores are below 2.50 which indicate that respondents' disagreed with the statements. The grand mean score of 2.31 which is belowthe accepted mean score of 2.50 indicates disagreement in principals' motivational practicesto promote teachers' instructional improvement to promote teachers' instructional improvement forsustainable development in secondary education in Anambra State.

\section{DISCUSSION}

The findings on table 1 show that secondary school principals in Anambra State do not engagein instructional supervisory practicesof observing classroom instruction to ensure cur iculum coverage, monitoring teachers' compliance to school schedules, meeting regularly with teachers to discuss instructional challenges and providing feedback to teachers after class observation. This finding is similarto that of Nwite (2016), which revealed that failure of the school principal to effectively supervise classroom instructions as a result of some administrative problems which impacts negatively on teaching and learning as well as cur iculum implementation. However, checking of teachers lesson plan and lesson notes for possible guidance, checking teachers' record of work done to monitor their progress and monitoring teachers' use of instructional materials are instructional supervision practices, should be engaged in by principals' to promote teachers' instructional improvement for sustainable development in secondary schools in Anambra State. The grand mean of 2.44 which is taken as disagreement indicate that secondary school principals in Anambra State do not adequately engage in instructional supervision practicesto promote teachers' instructional improvement for sustainable development in secondaryeducation.

Findings on table 2 show that secondary school principals in Anambra State do not engage in motivational practices of acknowledging teachers' instructional achievement openly, providing instructional facilities to enhance instructional delivery, facilitating prompt payment of salary and allowances and awarding teachers with impressive titles to boost their morale to promote instructional improvement. This finding is in agreement with the earlier report of Akinfolarin and Ehinola(2014)which concluded that the school head fairly provides regular paymentofsalaryand other remuneration to lecturers (teachers) and do not appreciate their lecturer's work openly among others. Prompt payment of teachers' salaries is key to their extrinsic motivation for productivity. However, motivational practices of recommending teachers forpromotion as at when due, involving teachers in decision making on instructional progress, establishing good relationship 
with teachers, and providing adequate chances for professional growth and research development should be engaged in by principals' to promote teachers' instructional improvement.

\section{RECOMMENDATIONS}

Based on the findings of this study, the following recommendations were made:

1. School administrators' should always engage in instructional supervisory practices by observing classroom instruction to ensure cur iculum coverage, monitoring teachers' compliance to school schedules, meeting regularly with teachers to discuss instructional challenges and providing feedback to teachers after class observation.

2. School administrators and managers should engage in motivational practices of acknowledging teachers' instructional achievement openly, providing instructional facilities to enhance instructional delivery, facilitating prompt payment of salaries and allowances and awarding teachers with impressive titles to boost their morale for instructional improvement.

\section{CONCLUSION}

The poor academic performance of secondary school students in Nigeria due to inability of teachers to adequately cary out their instructional delivery task is worisome. This study concluded that instructional supervision practices are not adequately engaged in by secondary school principals' in Anambra State to promote teachers' instructional improvement. The study also concluded that secondary school principals' do not engage in adequate motivational practicesfor teachers' instructional improvement in secondary schools in Anambra State. Providing management support for workersis crucial as they are the toolsfor achieving productivity in any enterprise. Management support practices give workers the sense of being part of the organization, they feel loved and cared for as such, put in their best towards organization's growth and development.

\section{REFERENCES}

1. Akinfolarin, A. V. \& Rufai, R. B. (2017). Extent of information and communication technology (ICT) utilization for students' learning in tertiary institutions in Ondo State, Nigeria. International JournalofAdvanceResearchandInnovativeIdeasin Education,3(3),2369-2376.
2. Akinfolarin,A.V\&Ehinola,G.B.(2014)."Motivatio nandeffectiveperformanceofacademicstaff inhighereducation (casestudyofadekunleajasinuni versity,OndoState,Nigeria)".International J ournal of Innovation and Research in Education Sciences, 1(2), 157-163.

3. Burton, L., Carper, K. C and William, V. (2011).The sociological of educational supervision and evaluation. J ournal of CrossDisciplinary Perspective in Education, 4(1) 2433.

4. Castller, A. O. (2010)

Managementsupportqualificationandgenderontea chers'performanceatan in-service course. Nigerian J ournal of School Leadership, 15(1), 12-17.

5. Clark,P.Y.(2015).Teachersasdesignersinselfdirectedlearning.InA.HargreavesandG.Fullan (Eds.).Understanding teacherdevelopment. New York: Teachers CollegePress.

6. Emetarom, U. G. (2007). "Instructional supervisory skills foreffective school management for

headteachersandsupervisorsinprimaryschoolsyst eminEbonyistate,Nigeria. "Apaper delivered at the workshop on improving skills on school management forhead teachers and supervisors.

7. Odumodi, A. C. (2011). Principals' management practices in secondary schools in Anambra State Unpublished M.Ed Thesis, University of Nigeria, Nsukka.

8. Okobia, T.A. (2015). Approaches to supervision of instruction, education and development.J ournal of the Nigerian Educational Research Council, 2(1), 292-299.

9. Nwite, O. (2016a). Principals' management support practices forenhancing teachers' performance in secondary schools in Nigeria. International $J$ ournal of Education, Learning and Development, 4(3), 26-36

10. Nwite, O. (2016b). Principals' performance of supervision of instruction in secondary schools in Nigeria.British J ournal of Education, 4(3), 4052.

11. Osakwe, N. R. (2010). Relationship between principals' supervisory strategies and teachers' instructional performance in Delta North senatorial District, Nigeria. Pakistan J ournal of Social Sciences, 7(6),437-440.

12. Peretomode V.F.(2013).Theories of management: Implications foreducational administration. Abraka: J ustice J eco Printing \& Publishing Global Delta State.

13. Yuniah K. M, Walter B. O., Duke N. N.(2015) Determinants of teacher motivation in public secondary schools in masaba south sub-county, Kenya. International $J$ ournal of Economics, CommerceandManagementUnitedKingdom,3(6). 